\title{
Abstracts
}

\section{8th ANNUAL MEETING}

\section{European Society for Paediatric Endocrinology}

\author{
Ulm, Germany, June 20-23, 1979
}

\author{
President: Walter Teller, Germany \\ Secretary: Raphael Rappaport, France \\ Treasurer: Pierre Sizonenko, Switzerland \\ Council: Frank Bidlingmaier, Germany \\ Cathrin Dacou-Voutetakis, Greece \\ David Grant, United Kingdom \\ Martin Ritzen, Sweden
}

F. DULANG * $^{*}$ C. THILLY*, P. BOURDOUX*, R. LAGASSi*,

A.M. LRMANS* (Intr, by R. WOLTLR). Depts. of Paediatrics, Radioisotipes and Epidemiology, Univ. of Brussels, Belgium.

Coitrogens and congenital hypothyroidism in man and in rats. Increased thiocyanate ( $\mathrm{SCN}$ ) formation resulting from ingestion of cassava constitutes one etiological factor of endemic goitre in Central Africa. We assessed whether such an increased SCN supply in pregnant and lactating mothers influences the thy roid function of newborns and of breastfed infants in the endemic goitre area of Ubangi (Zaire) and in rats. 1) The mean serum levels of $S \mathrm{SN}$ in pregnant women, mothers and newborns at delivers lactating mothers and breastfed infants ( 438 subjects) were 1.5 to 3 times higher than in 143 Belgian controls ( $P<0.001)$. At delivery, there was a linear correlation between the SCN levels in the mothers and in cord blond $(r=0.843, P<0.001)$. Serum lerb vels of TSH and $T_{4}$ in cord blond and in breastfed infants indicated biochemical evidence of congenital hypothyroidism in about $1 / 10$ subjects $(\mathrm{TSH}\rangle 100 \mathrm{uU} / \mathrm{ml}, \mathrm{T}_{4}\langle 5 \mathrm{ug} / \mathrm{dl})$. In the newborns, these parameters were correlated with the maternal urinary I/SCN ratio during pregnancy $(P<0.01) .2)$ Iodine deficient pregnant and lactating rats were supplemented with $S C N$ and PTU, $10 \mathrm{mg} / \mathrm{day}$. As compared to controls, the weights of the thyrids in the pups showed a 3 fold increase at birth and a 7 fold increase at the time of weaning( 16 days). Conclusion : In man and in rats, SCN impairs the thyroid function of newborns and of lactating infants and, in the presence of iodine deficiency, may play a role in the development of congenital hypothyroidism.

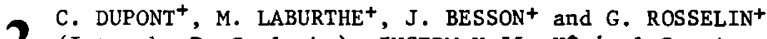
2 (Intr. by P. Canlorbe), INSERM U.55, Hôpital St. Antoine, Paris $12^{\circ}$, France. Stimulation of cyclic AMP (cAMP) accumulation in epithelial cells of human colon by plasma from children with watery diarrhea syndrome (WDS): role of vasoactive intestinal peptide (VIP).

The effect of plasma sampled in 2 children with wDS related to ganglioneuroblastoma was tested on the cultured cell line HT 29, derived from adenocarcinoma of human colon, that was found to possess a highly sensitive $\left(3 \times 10^{-12} \mathrm{M}\right)$ cAMP system specific for VIP. Results showed that: 1) plasma from children with WDS strongly stimulated CAMP accumulation in HT 29 cells, whereas plasma from normal children did not elicit any significant rise; 2) stimulation induced by serial diluticns of plasma from children with WDS paralleled the dose-effect of standard VIP; 3 ) there was no more stimulating effect when plasma was previously exposed to specific anti-VIP antibody; 4) plasma sampled after arrest of diarrhea, either spontaneous or following surgical resection of the tumor, was ineffective; 5) stimulation elicited by acid extracts of tumors and by standard VIP were identical. Further assessment of the biological significance of these data was provided by epithelial cells isolated from normal human colon. In these cells, cAMP accumulation was also stimulated by plasma from children with WDS. It can be concluded that the systems studied provide useful models for measurement of the biological effect of plasma from children with WDS on human intestinal epithelium. It appears that, at least in some cases, WDS is related to circulating VIP.
3 R.P. WILLIG and C. SCHRODER*

3 Dept. of Pediatrics, University of Hamburg, FRG Melatonin Plasma Levels and Circadian Rhythms in Children.

Melatonin, the best-known pineal hormone can be determined by RIA for fewer than 5 years. There are scanty data in children only, though this age group may be of greatest interest because of speculated connections between the pineal organ and puberty.

A specific plasma melatonin RIA (Stockholm antibody) was used following extraction with methylene chloride $(67 \%)$. The antigen-antibody complex was precipitated with ammonium sulfate. Intra- and inter-assay-variations were 8.9 and $11.2 \%$, respectively.

60 children (28 female and 32 male) with a mean age of 10 years (range: 0.8 - 18.3) had low plasma melatonin levels at day time $(x=13.0$, range $=0-33, S D=9.3 \mathrm{ng} / 1)$. At night time $(0.00-4.00 \mathrm{~h})$ melatonin increased significantly $(p<0.01)$ up to $200 \mathrm{ng} / 1 \quad(\bar{x}=130)$. There were no sex differences.

24 hour variations were seen when melatonin was determined every two hours in pathologic conditions: dexamethasone seems to suppress peak levels in the night in Cushing-syndrome and CAH. In a 2 months old child with seizures melatonin was decreased as well as in a boy treated with ACTH because of Lennoxsyndrome, a girl with craniopharyngeoma, and a patient with pinealoma. 3 girls suffering from precocious puberty showed circadian melatonin rhythms with high night peak levels.

This study was supported by DFG, SFB 34 Endocrinology

D.C. MOORE* P.C. SIZONENKO, D. LAUFER*, L. PAUNIER*

4 A. BEAUMANOI $R^{\star}$ and A. NAHORY*. Department of Pediatrics and Genetics, and EEG Laboratory, Department of Neurology, Geneva School of Medicine, Geneva, Switzerland. Melatonin secretion in relation to sleep in epileptic and control children and adolescents.

Serum melatonin (MT) levels were measured by radioimmunoassay at 4 hour intervals from $12.00 \mathrm{am}$ to $8.00 \mathrm{am}$ (darkness $8.00 \mathrm{pm}$ $7.00 \mathrm{am})$ with simultaneous EEG tracing in 22 epileptic patients aged 8 to 21 years. Mean levels for all patients at $12.00 \mathrm{pm}$ and 4.00 am were respectively $43+7$ and $55 \pm 10 \mathrm{pg} / \mathrm{ml}$ (mean $\pm \mathrm{SEM}$ ). There was no significant difference in mean peak leve $\bar{l}$ s of MT at $4.00 \mathrm{am}$ among non-treated (mean $=62+19 \mathrm{pg} / \mathrm{ml}, \mathrm{n}=6$ ), valproic acid-treated (mean $=48+13 \mathrm{pg} / \mathrm{ml}, \mathrm{n}=10$ ) and patients treated with other medications (mean $62+29 \mathrm{pg} / \mathrm{ml}, \mathrm{n}=3$ ). Three treated patients who had epileptic discharges through the night had a mean peak of only $32+5 \mathrm{pg} / \mathrm{ml}$ and were not included in the subsequent analysis. Analysis of MT levels according to sleep stages revealed that MT values after 2 or more episodes of REM sleep $(86 \pm 20 \mathrm{pg} / \mathrm{ml})$ were significantly higher than those after no preceeding episodes $(31 \pm 6 \mathrm{pg} / \mathrm{ml}, \mathrm{P}<.0001)$ and even than those after one preceeding episode $(48+8 \mathrm{pg} / \mathrm{ml}, \mathrm{P}<.05)$. For comparison 8 normal males were studied hourly in the same fashion. Mean MT levels at 12.00 am and 4.00 am were $36+10 \mathrm{pg} / \mathrm{ml}$ and $50+9 \mathrm{pg} / \mathrm{ml}$ respectively. Likewise, MT values at 4.00 am varied directly with the number of preceeding episodes of REM sleep although the differences were not statistically significant. These results suggest that MT secretion may be related to REM sleep. 